\title{
Researching of university students sport consumption
}

\author{
Mahmut ELMAS ${ }^{1}$ Velittin BALCI \\ ${ }^{1}$ Ankara University, Faculty of Sport Sciences, Ankara, Turkey \\ Address Correspondence to M. Elmas, e-mail: mahmutelmas06@gmail.com
}

\begin{abstract}
The study determines the rank of consuming sport and sporting goods behavior of university students and presents ideas to develop this behaviour. Sport marketing and sport consuming litarature has been scanned in content of the research. The research has been applied by using a scale developed by Elmas et al. (8) which consist three dimensions as event consuming, media consuming and sporting goods consuming. After verifiying the scales reliabilitys and validity, normal distrubituon checked and one sample t-test for bileteral variables, one way anova test for multi variables applied. The study's scale has been applied by using random expample medhod on sophomore and further class students of university students in Ankara/Turkey to collect data. University students sport consuming status according to their demographic values are reported at end of the research. The scale has two parts, demographic informations as a first and sport consuming scale as second part. SPSS 20 has used to evaluate to collected data. It seems that male students consumes more sport than female students end of the research. Moreover according to results, while younger students attends sport related events more than older ones, students consumes more sporting goods who has middle income than high or low ones. Students who does any kind of sport or follows it consumes more sport in all three dimentions.
\end{abstract}

Key words:Marketing mix, Service marketing, Sport consuming, Student and sport

\section{INTRODUCTION}

There are a number of actions that we carry out in order to meet our basic needs and secondary needs such as drinking water, dressing, having fun and exercising. Consumption products sources can be ourselves, nature or other persons. According to İler et al. (10) in the progress of reaching to end user to those products which are provided by 3rd persons, in convenient place and stuations and by authorized people, there is a trading movement which can be valued by money, product, service, idea or experience. Consuming is a series of inevitable actions that every living creature has to do in order to survive. Based on this, considering the fact that people will consume throughout their lifes and young people are the consumers of both today and tomorrow, canalizing their current consumption habits is important for both the healthy society and future sports market.

Sports is an important consumption and trading product human life for personal and social health. While sporting organizations contribute directly to the country's economy as job opportunities and production elements, they play an important role in the construction sector with their employees such as architects, engineers and workers in the construction fields where sporting events take place and also play an important role in both domestic and foreign tourism as a free time activity (16). In addition to being a consumption product on its own, sports has been massively used as a tool of propaganda, education and economic development of governments or organizations and still continues to be used. Words of Salazar who is former Prime Minister of Portuguese 'I have managed the country forty years of 3F (Fiesta, Fadima and Football)' (15), supports this sentence. Therefore, the consumption of sports combines many facts which are related to each other or not. Volleyball, The increasing interest in sports has brought along the economic growth of the sports sector. The sport product is combination of a physical product, a service product or combination of them to provide benefit to the sport spectators, to athletes or to the companies that generate income through sports (2). While an exercise hall itself and the equipment in it represent the sport products, the instructor's work in the hall exemplifies the dimension of the sport's service. Not 
only sport related products but also other unrelated ones being marketed by using sports popularity. The sports industry is an important industry branch where companies can effectively promote their products and make brands their names (1).

structure Consumption choices of young people are in various ways such as food, clothing, communication, health, sports equipment, cosmetics and so on. Especially university students takes place in a large expenditure group by buying books, clothing and spending money on leisure time activities (7). With the help of these statistics, it is observed that university students are an age and status group suitable for sports in terms of selfdesire, resources and time. According to Loudon et al. (11), the brand preferences accepted in the youth period significantly affect the brand preferences of these people in the future. Therefore, the current consumption behavior of the students may turn into habit, and even after the end of their student years, they can maintain their consumption status.In this context, investment in these age groups in sports marketing is an investment not only for today but also for the future market. As stated in the "Sport Consumption Scale" developed by Elmas at al. (8), sports consumption is examined in 3 subdimensions;

\section{Sporting Goods Consumption}

Direct or indirectly related to sport (whether or not taken to participate in sport activity), the purchase of items such as balls, nets, jerseys, mascots, scarves and so on are covered by the consumption of sporting goods. Some of the sporting products offered by some of the major teams which their logo is printed on and credit cards with their names on, various virtual football games or virtual car races, a sneaker and a tennis racket are only a little part of sporting goods.

\section{Sports Media Consumption}

Following sport organizations on media because of stiations such as shortage of time, transportation problems, financial difficulties, has advantages to spectators who watches where the sport event take place. They can view replays from various angles and listen detailed comments (9). Not only on television and radio programs, but also on the internet, consumers can reach the goods or services they want 24/7 regardless of time and place. In particular, social media is increasing its popularity day by day in sports tracking because spectators can communicate with others while wathcing the event or later.

\section{Sports Events Consumption}

Professional-amateur persons who does sport or leisure time evaluators are considered as sports participants (2). Coaches, managers, statisticians, followers etc. who are currently taking part in the sports event are the subject of event consumption. So sports; In addition to being a professional or amateur activity area, it is a product of recreational activities in which leisure time is evaluated.

\section{MATERIAL \& METHOD}

The research was conducted with a crosssectional approach and a relational survey model. This study was carried out with the voluntary participation in the randomly selected students (students of the sports sciences faculty were not included in the study) in Gazi University and Ankara University. In the simple random sampling method, each element constituting the universe has the chance to enter the sample. Therefore, the value to be given to each element in calculations is the same (3). Once the unconditional surveys has not included a total of 703 survey questionnaires were proccessed by IBM SPSS 20 (Statistical Package for the Social Sciences) and has been the source of the content of the thesis. The minimum number of samples determined from total number of the students by the formula (3) and 0,05 error rate used for it purpose. 
Table 1. Demographic values of applicants

\begin{tabular}{cccc}
\hline Variables & Group & Numbers & Percentages \\
\hline \multirow{2}{*}{ Age } & 20 or less & 229 & 32.6 \\
& between 21-25 & 390 & 55.5 \\
\cline { 2 - 4 } & 26 or more & 84 & 11.9 \\
\cline { 2 - 4 } Gender & Male & 339 & 48.2 \\
\cline { 2 - 4 } & Female & 364 & 51.8 \\
\hline \multirow{2}{*}{ Income (Monthly) TL } & 500 or less & 249 & 35.4 \\
\cline { 2 - 4 } & $501-1300$ & 232 & 14.0 \\
\cline { 2 - 4 } & $1301-2000$ & 101 & 17.2 \\
\hline TOTAL & 2001 or more & 121 & 100 \\
\hline
\end{tabular}

The sample of the study was consisted of 703 students which are 339 male and 364 female aged $\% 32$ twenty or less, $\% 55,5$ between twenty one and twenty five, \%11,9 twenty six and more. 35,4 percent of them has 500 or less Turkish Liras per month income, 33 percent of them has 501-1300 TL, 14,4 percent of them has between 1301 and 2000 Turkish Liras income while 17,2 percent of them has more then 2001 Turkish liras per month.

The scale which is used in the research and developed by Elmas et al. (8) titled 'Sport Consuming Scale' consists two parts, 7 questions about demographic informations as first and 13 questions about sport consumption as second part. The items were formed according to the 5's Likert scale. The Cronbach Alpha test was used to measure the internal reliability of the data. According to Kayış (2006); the reliability of the scales Cronbach Alpha $(\alpha)$ coefficient is interpreted as follows:

- $0,00 \leq \mathrm{a}<0,40$ is not reliable

- $0,40 \leq \mathrm{a}<0,60$ is low reliable

- $0,60 \leq \mathrm{a}<0,80$ is reliable

- $0,80 \leq \mathrm{a}<1,00$ is high reliable

Table 2. Sport Consuming Scale Reliabilty Test

\begin{tabular}{cc}
\hline Dimension & Cronbach'a Alpha \\
\hline Sporting Goods & .701 \\
\hline Media & .772 \\
\hline Events & .852 \\
\hline General &, 885
\end{tabular}

According to Devellis (2003) in all dimensions, it was found to be consistent over 0.700 , which is the acceptable value. Frequency, percentage, arithmetic mean and standard deviation values were used in the evaluation of demographic characteristics. Independent Sample $\mathrm{T}$ Test was used to test consumption differences according to gender and One Way ANOVA was used to find consumption differences between other multiple variables. The LSD Post Hoc test was used to determine the statistical differences between the groups. 


\section{RESULTS}

\begin{tabular}{|c|c|c|c|c|c|c|c|c|}
\hline SUB DIMENTIONS & Gender & $\mathrm{N}$ & Ort. & $\begin{array}{c}\text { Mean } \\
\text { Difference }\end{array}$ & $S$ & sd & $\mathrm{t}$ & $\mathrm{P}^{*}$ \\
\hline \multirow{2}{*}{ Sporting Goods } & Female & 339 & 3.0639 & \multirow{2}{*}{.20161} & \multirow{2}{*}{.65547} & \multirow{2}{*}{701} & \multirow{2}{*}{2.904} & \multirow{2}{*}{.004} \\
\hline & Male & 364 & 3.2655 & & & & & \\
\hline \multirow{2}{*}{ Media } & Female & 339 & 2.8242 & \multirow{2}{*}{.5143} & \multirow{2}{*}{.51432} & \multirow{2}{*}{701} & \multirow{2}{*}{6.820} & \multirow{2}{*}{.000} \\
\hline & Male & 364 & 3.3385 & & & & & \\
\hline \multirow{2}{*}{ Events } & Female & 339 & 2.1231 & \multirow[t]{2}{*}{.48577} & \multirow{2}{*}{.48577} & \multirow{2}{*}{701} & \multirow{2}{*}{6.315} & \multirow{2}{*}{.000} \\
\hline & Male & 364 & 2.6088 & & & & & \\
\hline \multirow{2}{*}{ General } & Female & 339 & 2.6704 & \multirow{2}{*}{.40057} & \multirow{2}{*}{.40057} & \multirow{2}{*}{701} & \multirow{2}{*}{6.804} & \multirow{2}{*}{.000} \\
\hline & Male & 364 & 3,0709 & & & & & \\
\hline
\end{tabular}

T-test analysis results displayed on table 3 which measures if there are differences of sport consumption according to gender $[\mathrm{t}(701)=2,904$; $\mathrm{p}<, 05]$ indicates that sporting goods consumption of university students doesnt have any differences. Mean differences of females $(X=30639)$ less than males $(X=3,2655)$ so seems that males consumes more sporting goods than females.

Media consumption rates according to relations between gender and following sports media as sub dimention analysed by $\mathrm{t}$-test $[\mathrm{t}(701)=6,820 ; \mathrm{p}<, 05]$ and found that there is no differences. As a result of mean differences females media consumption are $(X=2,8242)$ less than male's ones $(X=3,3385)$ so as a result males consumes more sports media than females.

Events consumption rates according to relations between gender and attending to sport events as sub dimention analysed by t-test $[\mathrm{t}(701)=6,315 ; \mathrm{p}<, 05]$ and found that there are differences between them. As a result of mean differences, females consumes sport events less than $(X=2,1231)$ males $(X=2,6088)$.

In general according to $\mathrm{t}$-test $[\mathrm{t}(701)=6,804$; $\mathrm{p}<, 05]$ there is difference between gender and sport consumption in relation. Females consumes sport less than $(X=2,6704)$ males $(X=3,0709)$. So according to this results males consumes sports more than females in general.

\begin{tabular}{|c|c|c|c|c|c|c|c|c|}
\hline SUB DIMENTIONS & Age & $X$ & $\mathrm{df}$ & $\begin{array}{l}\text { Sum of } \\
\text { Squares }\end{array}$ & Mean of Squares & $\mathrm{F}$ & $\mathrm{P}^{*}$ & $\begin{array}{c}\text { Dif. } \\
\text { (LSD) }\end{array}$ \\
\hline \multirow{3}{*}{ Sporting Goods } & (a) 20 or less & 3.1845 & 2 & & \multirow{3}{*}{$\begin{array}{l}.439 \\
.855\end{array}$} & \multirow{3}{*}{.514} & \multirow{3}{*}{.598} & \\
\hline & (b) $21-25$ & 3.1321 & 700 & $\begin{array}{c}.8 / 8 \\
598.315\end{array}$ & & & & \\
\hline & (c) 26 or more & 3.2321 & & 599.193 & & & & \\
\hline \multirow{3}{*}{ Media } & (a) 20 or less & 3.0622 & & & \multirow{3}{*}{$\begin{array}{l}1.187 \\
1.058\end{array}$} & \multirow{3}{*}{1.122} & \multirow{3}{*}{.326} & \\
\hline & (b) $21-25$ & 3.1096 & 700 & 2.374 & & & & \\
\hline & (c) 26 or more & 2.9256 & 702 & $\begin{array}{l}740.525 \\
742.899 \\
\end{array}$ & & & & \\
\hline \multirow{3}{*}{ Events } & (a) 20 or less & 2.4576 & & & \multirow{3}{*}{$\begin{array}{l}2.607 \\
1.082\end{array}$} & \multirow{3}{*}{2.410} & \multirow{3}{*}{.034} & \multirow{3}{*}{$\mathbf{c}<\mathbf{a}$} \\
\hline & (b) $21-25$ & 2.3374 & 700 & 5.215 & & & & \\
\hline & (c) 26 or more & 2.1762 & 702 & $\begin{array}{l}757.345 \\
762.560\end{array}$ & & & & \\
\hline \multirow{3}{*}{ General } & (a) 20 or less & 2.9015 & 2 & .950 & \multirow{3}{*}{$\begin{array}{l}.475 \\
.646\end{array}$} & \multirow{3}{*}{.736} & \multirow{3}{*}{.480} & \\
\hline & (b) $21-25$ & 2.8597 & 700 & 451.953 & & & & \\
\hline & (c) 26 or more & 2.7780 & 702 & 452.953 & & & & \\
\hline
\end{tabular}

One way anova analysis results displayed on table 4 which measures if there are differences of sport consumption according to age $[\mathrm{t}(701)=2,904$; $\mathrm{p}<, 05]$ indicates that sporting goods, sport media and general sport consumption of university students doesnt have any differences according to gender. 
University students sportive events ages 20 or less consumes more sport $(=2,4576)$ consumption according to age has differences as a compared to ages 21 or over $(=2,1762)$. result of one wa anova analysis $[\mathrm{F}(2,700)=2,410$; $\mathrm{p}<$ $0,05]$. LSD test has been appiled to find out the group which makes the difference and resulted as

\begin{tabular}{|c|c|c|c|c|c|c|c|c|}
\hline SUB DIMENTIONS & Income & $X$ & $\mathrm{df}$ & $\begin{array}{l}\text { Sum of } \\
\text { Squares }\end{array}$ & $\begin{array}{l}\text { Mean of } \\
\text { Squares }\end{array}$ & $\mathrm{F}$ & $\mathrm{P}^{*}$ & $\begin{array}{l}\text { Diff. } \\
\text { (LSD) }\end{array}$ \\
\hline \multirow{4}{*}{ Sporting Goods } & (a)500 or less & 3.0572 & \multirow{4}{*}{$\begin{array}{c}3 \\
699 \\
702\end{array}$} & \multirow{4}{*}{$\begin{array}{c}7.887 \\
591.307 \\
599.193\end{array}$} & \multirow{4}{*}{$\begin{array}{c}2.629 \\
.846\end{array}$} & \multirow{4}{*}{3.108} & \multirow{4}{*}{.026} & \multirow{4}{*}{ a. $c<b$} \\
\hline & (b) 501-1300 & 3.2802 & & & & & & \\
\hline & (c)1301-2000 & 3.0520 & & & & & & \\
\hline & (d)2001 or more & 3.2376 & & & & & & \\
\hline \multirow{4}{*}{ Media } & (a)500 or less & 2.9809 & \multirow{4}{*}{$\begin{array}{c}3 \\
699 \\
702\end{array}$} & \multirow{4}{*}{$\begin{array}{c}12.410 \\
730.489 \\
742.899\end{array}$} & \multirow{4}{*}{$\begin{array}{l}4.137 \\
1.045\end{array}$} & \multirow{4}{*}{3.958} & \multirow{4}{*}{.008} & \multirow{2}{*}{$\mathrm{a}<\mathrm{b}$} \\
\hline & (b) 501-1300 & 3.2575 & & & & & & \\
\hline & (c)1301-2000 & 2.9282 & & & & & & \\
\hline & (d)2001 or more & 3.0248 & & & & & & $\mathrm{D}<\mathrm{C} . \mathrm{A}$ \\
\hline \multirow{4}{*}{ Events } & (a)500 or less & 2.2530 & \multirow{4}{*}{$\begin{array}{c}3 \\
699 \\
702\end{array}$} & \multirow{4}{*}{$\begin{array}{c}7.657 \\
754.903 \\
762.560\end{array}$} & \multirow{4}{*}{$\begin{array}{l}2.552 \\
1.080\end{array}$} & \multirow{4}{*}{2.363} & \multirow{4}{*}{.026} & \multirow{4}{*}{$a<b$} \\
\hline & (b) $501-1300$ & 2.4647 & & & & & & \\
\hline & (c)1301-2000 & 2.2515 & & & & & & \\
\hline & (d)2001 or more & 2.4545 & & & & & & \\
\hline \multirow{4}{*}{ General } & (a)500 or less & 2.7637 & \multirow{4}{*}{$\begin{array}{c}3 \\
699 \\
702\end{array}$} & \multirow{4}{*}{$\begin{array}{c}8.512 \\
444.391 \\
452.903\end{array}$} & \multirow{4}{*}{$\begin{array}{c}2.837 \\
.636\end{array}$} & \multirow{4}{*}{4.463} & \multirow{4}{*}{.004} & \multirow{4}{*}{ a.c $<$ b } \\
\hline & (b) $501-1300$ & 3.0008 & & & & & & \\
\hline & (c)1301-2000 & 2.7439 & & & & & & \\
\hline & (d)2001 or more & 2.9056 & & & & & & \\
\hline
\end{tabular}

${ }^{*}(\mathrm{p}<0,05)$

To find out sport consumption rates of university students according to their income levels, one-way analysis reported at Table 5. According to the income level of the university students, there was a significant difference between the means at the level of 0.05 (the distribution of the data was homogeneous) $[\mathrm{F}(3,699)=3,108 ; \mathrm{p}<0,05]$.

According to the results of the LSD test conducted to find the difference group. The consumption level of consuming sportive product ( $=3.0572$ ) with students whose income level of 500 Turkish Liras or less is less than the income level of between 501-1300 Turkish Liras (= 3.2802). The income level of the students whose income level is between 1301-2000 Turkish Liras is lower in the sportive product consumption sub-dimension ( $=3,0520$ ) compared to the income level of 501-1300 Turkish Liras $(=3,2802)$.

There was a significant difference between the means at the level of 0.05 as a result of the one-way analysis to sports media consumption according to the income level of the university students $[\mathrm{F}(3,699)=$ $3,958 ; p<0,05]$. According to the results of the LSD test conducted to find the difference group. The level of consumption of consuming sport media between students with income of 500 Turkish Liras or less is lower than those with income level of 5011300 Turkish Liras (= 3,2575). The students who

\section{have income between 501 and 1300 Turkish Liras in} the sub-dimension of consumption of sports media ( $=3,2575)$ is lower than those with income of 13012000 Turkish Liras $(=2,9282)$. The income level of the students who have income between 501 and 1300 Turkish Liras in the sub-dimension of consumption of sports media $(=3,2575)$ is less than the income level of 2001 or more Turkish Liras $(=3,0248)$. There was a significant difference between the means at the level of 0.05 as a result of the one-way analysis to sportive events consumption according to the income level of the university students $[\mathrm{F}(3,699)=$ $3,958 ; \mathrm{p}<0,05]$. According to the results of the LSD test conducted to find the difference group. The level of consumption of sports activities in the sub dimension $(=2,9809)$ of the sports activities of the students with income less than 500 Turkish Liras or less is less than the income level of 501-1300 Turkish Liras $(=3,2575)$.

The income level of the students between 501 and 1300 Turkish Liras in general have higher sports consumption ( $=2,7439)$ according to the income level of between 1301-2000 Turkish Liras ( =3,0008).

\section{DISCUSSION}

According to Özbey and Güzel (13) in Turkey, despite the International Olympic Committee and the TMOK to encourage female to sport the initiative, compared to the many countries in the world's supporting the projects, the value given to 
female sports and sportsmen in Turkey has not yet reached the desired level. The findings shown in Table 2 support this study.

In another study, 118 males and 164 females from the Faculty of Education of Mehmet Akif Ersoy University replied that $63 \%$ of males active in sports, while the rate of $30 \%$ in females and males devoted more time to sporting activities than girls (14). The reasons for the fact that the females consumed sport less than males may have limitations due to the socio-cultural structure. In their study Balc1 and İlhan (4) found that female students had less active participation in activities than male students and less time in their activities.

According to the research conducted by the General Directorate on the Status and Problems of Women in 2000, the ratio of the females who follows sports programs were $5 \%$. This is similar to the conclusion that the females mentioned in Table 3 consume less sports media than males. Considering that the females consumed less sport products as shown in the same chart, the fact that they consume less sports media of course, being parallel to this situation.

Considering the fact that university students ages are mostly close to each other (Table 1), the difference between the consumption of sporting media and sporting products does not show a significant difference compared to their age. In the literature search, we did not find any study examining the sports consumption differences of the students in the age range mentioned in the table. However, the ratio between the consumption of the two extremes, which are the two endpoints we take as demographic information who are 26 or more consumes less than that of the youth. Supporting our findings, Voigt (18) studied that depending on the increasing age results as decrease in the rate of doing sports. It can be said that the factors such as the dynamism of being younger, the responsibilities that take over the individuals as the age progresses and the lack of time may have been effective in looking at their age.

According to Mullin et al. (12), the target audience of sports promotions in the last century is the young people whish leads more number of young athletes. This situation supports the findings of our study. In addition, another study supporting our study was carried out by Tetik (17) and $56.2 \%$ of the members who attended the sports facilities were found to be 35 or less.
According to Cemalcilar (6), the income situation is an important factor affecting the consumption behavior of individuals. Our study is parallel to the explanation. However, Yalçın et al. (19) found that income level is not a significant factor in active sports consumption, it has resulted in the opposite of our findings and researches of Cemalcilar.

Bayraktar and Sunay's (5) study shows that time loss occurs because of so much human labor in Turkey's facilities. This reduces the income level of the employed people, requires additional work and eliminates the free time that should be reserved for sports. This study may be one of the reasons for the decrease in sport consumption in Table 4.

It is observed that university students are an age and status group suitable for sports in terms of self-desire, resources and time. According to Loudon et al. (11), the brand preferences accepted in the youth period significantly affect the brand preferences of these people in the future. Considering the directive effects of media on human sub-consciousness, it will be inevitable that people will increase their consumption in both sportive product and efficiency consumption sub-dimensions as sports media consumption rates increase. This is possible by using various social media channels as a more effective dissemination tool. As a new trend, sports dances, clothes, box openings, exercise movement sugestions, sports events can be created to provide significant increase in sports consumption.

It can be another research topic to examine whether the sporty products sold by a sporting provider are more or less consumed by people who are engaged in sports or who are not interested in sports, but who are more interested in the effects of such elements as comfort or fashion.

\section{REFERENCES}

1. Akkaya Y. Spor Pazarlamasında Ürün Kavramının Incelenmesi. International Journal Of Science Culture And Sport, 2016;4-3.

2. Argan M, Katırcı H. Spor Pazarlaması, Nobel Yayın, Ankara, 2015.

3. Arıkan R. Araştırma Yöntem Ve Teknikleri, Gazi Kitabevi, Ankara, 2013.

4. Balcı, V , İlhan, A. Türkiye'deki Üniversite Öğrencilerinin Rekreatif Etkinliklere Katılım Düzeylerinin Belirlenmesi. Spormetre Beden Eğitimi Ve Spor Bilimleri Dergisi, 2006; 4(1): 11-18. 
5. Bayraktar B, Sunay H. Türkiye'de Elit Bayan Ve Male Voleybolcuların Voleybol Sporuna Başlamalarına Etki Eden Unsurlar Ve Spordan Beklentileri. Spormetre Beden Eğitimi Ve Spor Bilimleri Dergisi, 2007; (2):63-72.

6. Cemalcılar İ, Şahin M. Pazarlama. Anadolu Üniversitesi Yayınları, Eskişehir, 1990.

7. Çırpıcı F. Üniversite Öğrencilerinin Reklamlara Yönelik Tutum Ve Davranışları Üzerinde Bir Araştırma. Ankara Üniversitesi, Aile Ve Tüketici Bilimleri Anabilim Dalı, Yüksek Lisans Tezi, 2006.

8. Elmas M, Erdeveciler Ö, Balcı V. Spor Tüketim Ölçeği Geliştirme Çalışması, Uluslararası Rekreasyon Ve Spor Yönetimi Kongresi, Muğla; 2018.

9. Erdoğ Mo. Kitlesel Spor Faaliyetleri Özelinde Spor Pazarlaması; Bjk Örneği. Bahçeşehir Üniversitesi Yüksek Lisans Tezi, 2012.

10. İlter B, Bayraktaroğlu G. Kar Amacı Gütmeyen Sosyal İçerikli Pazarlama Uygulamaları. Erciyes Üniversitesi İktisadi Ve İdari Bilimler Fakültesi Dergisi, 2007:49

11. Loudon D, Dellabitta Aj. Consumer Behavior, Concepts And Applications. Mc Graw-Hill International Editions, New York, 1988.
12. Mullın Bj, Hardy S, Sutton Wa. Sport Marketing, Fourth Edition, Usa: Human Kinetics, 2014

13. Özbey S, Güzel P. Olimpik Hareket Ve Kadın. Balıkesir Üniversitesi Sosyal Bilimler Enstitüsü Dergisi, 2011;14(25):118.

14. Pepe K, Oflaz H.E, Koç İ. Mehmet Akif Ersoy Üniversitesi Eğitim Fakültesinde Okuyanöğretmen Adaylarının Boş Zaman Anlayış Ve Alışkanlıklarının Araştırılması. 9. Uluslararası Spor Bilimleri Kongresi, Muğla, 2006.

15. Sert M. Gol Atan Galip, Futbola Sosyolojik Bir Bakış. İstanbul: Bağlam Yayınları, 2000.

16. Sunay H. Sporda Organizasyon. Gazi Kitapevi, Ankara, 2010.

17. Tetik O. Spor Tüketicilerinin Spor Pazarlama Bileşenleri Hakkındaki Görüşlerinin İncelenmesi. Ankara Üniversitesi Sağlık Bilimleri Enstitüsü, Yüksek Lisans Tezi, Ankara, 2009.

18. Voıgt D. Spor Sosyolojisi. (Çeviri: Ayşe Atalay), Alkım Yayınları, İstanbul, 1998.

19. Yalçın Hb, Doğru Z, Yüktaşır B. Spor Tüketicisi Farklılıkları Ve Spor Pazarlaması Bileşenleri, Atatürk Üniversitesi Beden Eğitimi Ve Spor Bilimleri Dergisi, 2003:35-44. 